\title{
Recessions Accelerate Trend of Wives as Breadwinners
}

KRISTIN SMITH

$\mathrm{T}$ he Great Recession is widely acknowledged to be the worst financial situation since the Great Depression, setting new benchmarks in terms of job loss, unemployment rates, and length of time unemployed. ${ }^{1}$ From December 2007 to January 2010, the U.S. economy lost 8.7 million jobs, with the bulk of job loss occurring in the first quarter of 2009. ${ }^{2}$ Although the official end of the recession was in June 2009, job loss continued into January 2010. Since then, the economy has added jobs slowly, and despite twenty-six consecutive months of job gains (from June 2010 to September 2012), the economy has only gained 47 percent of the jobs lost, or 4.2 million, owing in part to job loss in the government sector since the end of the recession. ${ }^{3}$

The Great Recession has affected men's employment more than women's, with 69 percent of the jobs lost held by men. ${ }^{4}$ Overall unemployment reached a high of 10.0 percent in October 2009, with men's unemployment at 11.2 percent and women's at 8.7 percent. In September 2012, the unemployment rate dipped below 8 percent for the first time since January 2009..$^{5}$ Job loss has been particularly high among African American men, lower-educated men, and workers in male-dominated industries, such as construction and manufacturing. In contrast, the economy added jobs in some femaledominated industries, such as education and health services during the recession.

Married-couple families have responded to a husband's job loss with an increased dependence on wives' earnings. Research on the Great Recession shows that wives increased their labor force activity and increased their hours spent working for pay. ${ }^{6}$ The slow economic recovery means that American families continue to experience the pain of economic recession. The final toll of the Great Recession on families is still unknown, with family poverty rates rising and family income levels falling during the recession. Since the recession ended, poverty levels have begun to stabilize, but family income has continued to fall. ${ }^{7}$

This brief investigates the increased role employed wives played in family economic stability prior to, during, and in the two years after the Great Recession, and makes comparisons to the 1990-1991 and 2001 recessions.

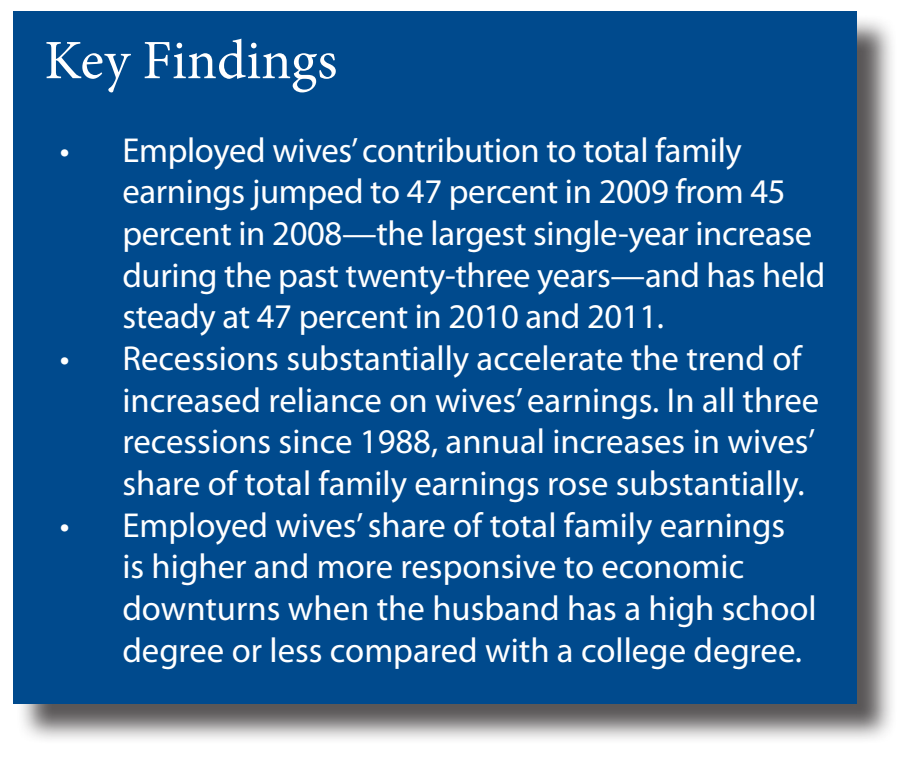

\section{Increased Reliance on Employed Wives' Earnings During Recessions}

One consequence of the Great Recession is a greater reliance on wives' earnings. As husbands lose their jobs and family earnings plummet, wives' earnings often help keep families afloat.

In 2007, just prior to the Great Recession, employed wives contributed 44 percent of total family earnings. During the Recession (two years later), their share of total family earnings rose by 3 percentage points, to 47 percent by 2009, a statistically significant rise, and the rate held steady in 2010 and 2011 (see Figure 1). ${ }^{8}$ This is not surprising given the slow job recovery and continued high unemployment rates among men. These changes affect families with children under 18 as well, for which the economic contribution of employed mothers also increased during the recession.

Figure 1 illustrates how recessions, and in particular the Great Recession, substantially accelerate the trend of an increased reliance on employed wives' earnings. From 1988 
Figure 1. Employed Wives' Percent Contribution to Total Family Earnings, 1988-2011

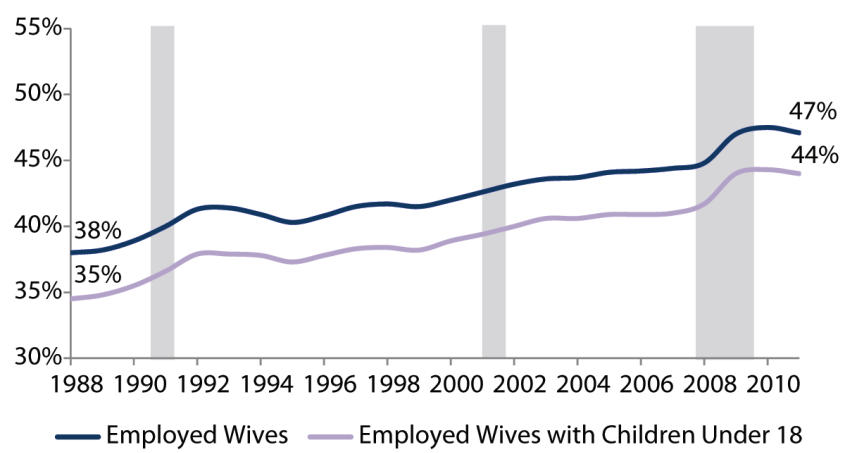

Source: 1989-2012 Current Population Survey, Annual Social and Economic Supplements. Note: Shaded bars indicate economic recessions.

to 2011 (a twenty-three year period), employed wives' share of total family earnings increased by 9 percentage points. In all three recessions during that time period, ${ }^{9}$ annual increases in wives' share rose substantially, and the increases were statistically significant. However, the largest single-year increase occurred during the Great Recession, from 2008 to 2009 , when wives' contribution rose by 2 percentage points.

\section{Wives' Contribution Is More Respon- sive to Economic Downturns When Husbands Have Less Education}

Job loss during the Great Recession has been particularly high among men with less education, and thus their struggles put added pressure on their wives. This translates into a greater reliance on wives as breadwinners. For example, women married to men with a high school degree or less contributed 51 percent of total family earnings in 2011, while women married to men with a college degree contributed 42 percent (see Table 1 ).

Table 1. Employed Wives' Percent Contribution to Total Family Earnings by Husband's Education

\begin{tabular}{lccc}
\hline & 2007 & 2009 & 2011 \\
\hline Total & 44 & 47 & 47 \\
Husband's education level & & & \\
$\quad$ High school or less & 48 & 52 & 51 \\
Some college & 45 & 48 & 49 \\
College graduate & 40 & 42 & 42 \\
\hline
\end{tabular}

Source: 2008, 2010, 2012 Current Population Survey, Annual Social and Economic Supplements.
Wives' share of total family earnings increased across all levels of a husband's education during the Great Recession, but it increased more among married couples where the husband had a high school degree or less. From 2007 to 2009, the contribution to total family earnings of employed wives in this group increased by 4 percentage points. In contrast, when husbands had a college degree, employed wives' contribution increased by 2 percentage points during the same time period.

This pattern among families with less-educated husbands was evident in previous recessions as well (see Figure 2). Clearly, wives' contribution to total family earnings was responsive to economic shocks and downturns among families with husbands with less education, primarily owing to increased joblessness among their husbands. On the other hand, among women whose husbands had a college degree, their contribution was less responsive to economic downturns. ${ }^{10}$

Figure 2. Employed Wives' Percent Contribution to Total Family Earnings by Husband's Education, 1988-2011

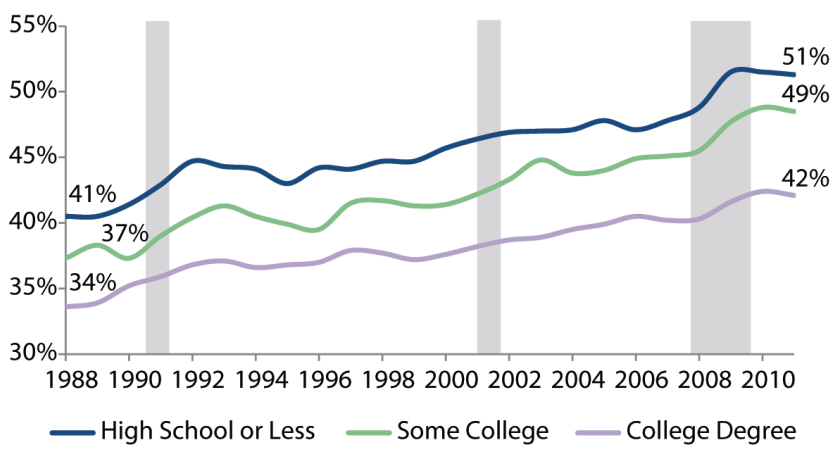

Source: 1989-2012 Current Population Survey, Annual Social and Economic Supplements. Note: Shaded bars indicate economic recessions.

\section{Implications of Increased Reliance on Wives as Breadwinners}

The massive job loss during the eighteen months of the Great Recession, primarily in male-dominated industries such as manufacturing and construction, coupled with sluggish job growth during the recovery, have left many families with lower earnings and have placed an unprecedented importance on wives' earnings to keep families afloat. If history is a good guide, it is likely that wives' share of total family earnings will not return to pre-recession levels, but rather, the Great Recession will serve to propel wives' contributions higher. It is likely that wives will remain in the labor force even after their husbands return to work, as many families have lost ground due to diminished savings, housing values, 
and retirement accounts. Thus, it is critical to pay attention to the implications of wives as breadwinners for families and the workplace.

As more wives enter the labor force and earn wages comparable to their husbands, gender roles can change. Mothers still do more housework than fathers, but fathers are spending more time with their children and their involvement in the family has increased. ${ }^{11}$ Recent research indicates that among fathers with an employed wife, the proportion of fathers who provide child care to their children increased over the Great Recession, with the employment status of the father playing a large role in whether he provided care for his children. ${ }^{12}$ More research linking changes in wives' and husbands' employment with their time spent doing housework and child care is needed to better understand the implications of the Great Recession on the division of labor in the home.

Families that experience male job loss and reduced earnings are stressed. Even prior to the recession, working families were under stress from increased time spent working, inflexible workplaces that have not kept pace with changing families, and the lack of policy supports. ${ }^{13}$ Policies to support working families, such as paid sick leave and paid family medical leave, affordable quality child care, livable wages, and measures that increase workplace flexibility, could help reduce the work and family conflict that many men and women experience. In addition, there is an obvious need for continued job creation, continued support for long-term unemployment, and expanded public assistance and food stamps to help families during this economic recovery.

Employed wives contribute 47 percent of family earnings, drawing attention to equity in the workplace. Women employed full-time, year-round earn 77 percent of what corresponding men earn. ${ }^{14}$ Clearly, family economic stability depends on wives' economic contributions, and families suffer when women earn less.

\section{Data Used}

This brief uses data from the U.S. Census Bureau's Current Population Survey (CPS) March Supplements and Annual Social and Economic Supplements IPUMS files compiled by the Minnesota Population Center from 1989 to 2012. "Wives' contribution to total family earnings" is the ratio of wives' annual earnings to the sum of wives' and husbands' annual earnings in the previous year of data collection. Employed wives are those with positive earnings in the previous year of data collection. All analyses are weighted using Census Bureau weights. Differences presented in the text are statistically significant at the 0.05 level.

\section{E N D N O T E S}

1. David Grusky, Bruce Western, and Chris Weiner, The Great Recession (New York: Russell Sage Foundation, 2011).

2. Bureau of Labor Statistics, "Economic and Employment Data" (Washington, DC: BLS, 2012), www.bls.gov/ data/\#unemployment (retrieved November 2, 2012).

3. Ibid.

4. Ibid.

5. Ibid.

6. Marybeth Mattingly and Kristin Smith, "Changes in Wives' Employment When Husbands Stop Working: A Recession-Prosperity Comparison," Family Relations, vol. 59 (2010):343-357.

7. See Carmen DeNavas-Walt, Bernadette Proctor, and Jessica Smith, "Income, Poverty, and Health Insurance Coverage in the United States: 2011" (Washington, DC: U.S. Census Bureau, 2012).

8. In 2011, 31 percent of wives age 18-64 were out of the labor force. When these nonearning wives are included, wives contribute 35 percent of total family earnings.

9. Three recessions occurred during the period of 1988 2011: from July 1990 to March 1991; from March 2001 to November 2001; and from December 2007 to June 2009. See the National Bureau of Economic Research for more information about business cycles: www.nber.org/cycles.html.

10. The annual rise in employed wives' share of total family earnings during the 2001 recession was not statistically significant among couples in which the husband had a college degree, but it was statistically significant during the 19901991 recession and the Great Recession.

11. Suzanne Bianchi, John Robinson, and Melissa Milkie, Changing Rhythms of American Family Life (New York: Russell Sage Foundation, 2006).

12. Lynda Laughlin, "A Slow Economy Can Increase Child Care Provided by Fathers" (Washington, DC: U.S. Census Bureau, December 5, 2011).

13. See Phyllis Moen, It's About Time: Couples and Careers (Ithaca, NY: Cornell University Press, 2003); Jerry Jacobs and Kathleen Gerson, The Time Divide (Cambridge, MA: Harvard University Press, 2004); Janet Gornick and Marcia Meyers, Families that Work: Policies for Reconciling Parenthood and Employment (New York: Russell Sage Foundation, 2003); and Ellen Gallinsky, Kerstin Aumann, and James T. Bond, "Times are Changing: Gender and Generation at Work and at Home" (New York: Families and Work Institute, 2011).

14. DeNavas-Walt et al., "Income, Poverty, and Health Insurance." 


\section{A C K N OW L E D G E M E N T S}

The author thanks Bruce Mallory, Marybeth Mattingly, Curt Grimm, Andrew Schaeffer, Amy Sterndale, Laurel Lloyd, and William Meub at the Carsey Institute; Rebecca Glauber, assistant professor of sociology at the University of New Hampshire; Debbie Stein, vice president of policy at the Hatcher Group; and Barbara Ray at Hired Pen for their assistance, comments, and suggestions.

\section{A B OUT THE A THOR}

Kristin Smith is a family demographer at the Carsey Institute and a research assistant professor of sociology at the University of New Hampshire (kristin.smith@unh.edu).

\section{A UNIVERSITY Ai of NEW HAMPSHIRE}

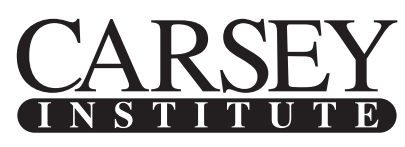

Building knowledge for families and communities

The Carsey Institute conducts policy research on vulnerable children, youth, and families and on sustainable community development. We give policy makers and practitioners timely, independent resources to effect change in their communities.

This work was supported by the Annie E. Casey Foundation, the W. K. Kellogg Foundation, and anonymous donors.

Huddleston Hall

73 Main Street

Durham, NH 03824

(603) 862-2821

www.carseyinstitute.unh.edu 